\title{
Starkeya koreensis sp. nov., isolated from rice straw
}

\author{
Wan-Taek Im, ${ }^{1}$ Zubair Aslam, ${ }^{1}$ Myungjin Lee, ${ }^{2}$ Leonid N. Ten, ${ }^{1,3}$ \\ Deok-Chun Yang ${ }^{4}$ and Sung-Taik Lee ${ }^{1}$
}

Correspondence
Sung-Taik Lee
e_stlee@kaist.ac.kr

\author{
${ }^{1}$ Department of Biological Sciences, Korea Advanced Institute of Science and Technology, \\ 373-1 Guseong-dong, Yuseong-gu, Daejeon 305-701, Republic of Korea \\ ${ }^{2}$ NeoPharm Co., Ltd, BVC-307, KRIBB, 52 Oeun-dong, Yuseong-gu, Daejeon 305-333, \\ Republic of Korea \\ ${ }^{3}$ National University of Uzbekistan, Students town, Tashkent 700-174, Uzbekistan \\ ${ }^{4}$ Department of Oriental Medicinal Material and Processing, College of Life Science, Kyung \\ Hee University, 1 Seocheon, Kihung Yongin, Kyunggi 449-701, Republic of Korea
}

\begin{abstract}
A facultatively chemolithoautotrophic, Gram-negative, aerobic, highly curved rod-shaped, nonmotile, non-spore-forming bacterium, strain Jip0 $8^{\top}$, was isolated from rice straw in Daejeon, South Korea. Strain Jip08 ${ }^{\top}$ produced colourless colonies $(1.0-1.5 \mathrm{~mm})$ on R2A medium after 3 days. On the basis of $16 \mathrm{~S}$ rRNA gene sequence similarity, strain Jip08 ${ }^{\top}$ was shown to belong to the $\alpha-2$ subclass of the Proteobacteria, and was most closely related to Starkeya novella IAM $12100^{\top}$ (98.6\%), Angulomicrobium tetraedale DSM 5895 ${ }^{\top}$ (98.1\%), Angulomicrobium amanitiforme NCIMB $1785^{\top}(98 \cdot 0 \%)$, Ancylobacter aquaticus ATCC $25396^{\top}(96 \cdot 6 \%)$ and Methylorhabdus multivorans $\mathrm{DM} 13^{\top}(95 \cdot 8 \%)$, all of which belong to the family Hyphomicrobiaceae. The genomic DNA G + C content of strain Jip08 ${ }^{\top}$ was 69 mol\%. Chemotaxonomic data [major ubiquinone, Q-10; major fatty acids, $\mathrm{C}_{18: 1}$ isomer (summed feature of $\left.\mathrm{C}_{18: 1} \omega 7 \mathrm{c} / \omega 9 \mathrm{t} / \omega 12 t\right), \mathrm{C}_{19: 0}$ cyclo $\omega 8 \mathrm{c}$ and $\left.\mathrm{C}_{16: 0}\right]$, 16S rRNA gene sequence analyses and some morphological and physiological features supported the affiliation of strain $\mathrm{Jip} 8^{\top}$ to the genus Starkeya. However, DNA-DNA hybridization data and some phenotypic properties showed that strain $\mathrm{Jip}_{0} \mathrm{8}^{\top}$ could be distinguished from the single known Starkeya species and represented a novel species, for which the name Starkeya

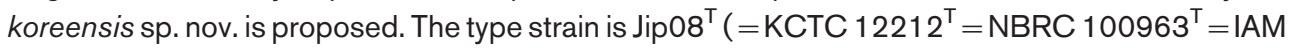
$15215^{\mathrm{T}}$ ).
\end{abstract}

The genus Starkeya was first described by Kelly et al. (2000), who proposed that Thiobacillus novellus should be reclassified as Starkeya novella; the genus Starkeya currently comprises only one species, S. novella IAM $12100^{\mathrm{T}}$ (Kelly et al., 2000). The genus Starkeya belongs to the family Hyphomicrobiaceae of the $\alpha-2$ subclass of the Proteobacteria, which also contains the genera Ancylobacter (Raj, 1983), Angulomicrobium (Vasil'eva et al., 1979), Azorhizobium (Dreyfus et al., 1988) and Methylorhabdus (Doronina et al., 1995). All of these genera form monophylogenetic clades in the phylogenetic tree based on 16S rRNA sequences (Fig. 1).

The genus Starkeya was created for the reclassification of $T$. novellus (Kelly et al., 2000). Ever since the genus Thiobacillus

The GenBank/EMBL/DDBJ accession number for the 16S rRNA gene sequence of strain $\mathrm{Jip}^{\mathrm{T}} 8^{\top}$ is $\mathrm{AB} 166877$.

A comparison of selected characteristics of strain $\mathrm{Jip} 08^{\top}$ and Starkeya novella IAM $12100^{\top}$ is available as supplementary material in IJSEM Online. was first described by Beijerinck (1904), the ability to grow with a reduced sulfur compound as a source of energy has been considered sufficiently important taxonomically to merit classifying all Gram-negative, sulfur-oxidizing, nonphototrophic rods in this genus. However, as studies using modern taxonomic methods have begun to show that some of the species are only superficially related, virtually every paper describing a novel Thiobacillus species in the last decade has mentioned the need to reorganize the genus. Most of this reorganization has now been done (Kelly \& Wood, 2000).

During the course of a study on the culturable aerobic bacterial community in environmental samples (Im et al., 2003) such as rice straw, anaerobic granular sludge (An et al., 2006; Aslam et al., 2005a; Bae et al., 2005; La et al., 2005), aerobic activated sludge (Aslam et al., 2005b; Quan et al., 2006), compost (H.-C. Yang et al., 2006) and soil from a ginseng field (D.-C. Yang et al., 2005, 2006) near Daejeon in Korea, a large number of novel bacterial strains were isolated 


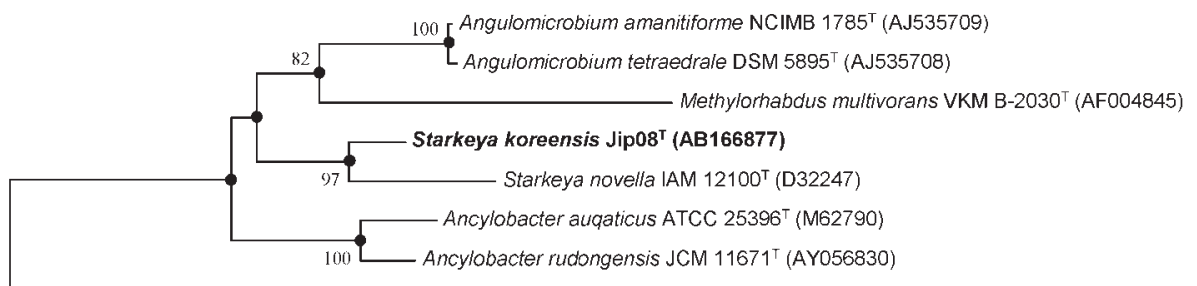

Azorhizobium caulinodans ATCC $43989^{\top}$ (D11342)

0.01

Fig. 1. Phylogenetic tree, constructed from a comparative analysis of $16 \mathrm{~S}$ rRNA gene sequences, showing the relationships between S. koreensis Jip $08^{\top}$ and related taxa. This tree was constructed from unambiguously aligned nucleotides by using the neighbour-joining and maximum-parsimony methods. Filled circles indicate generic branches that were also recovered using maximum-parsimony algorithms. Bootstrap values are expressed as percentages of 1000 replications. Bar, 1 substitution per 100 nucleotide positions.

that belonged to the Proteobacteria, Actinobacteria and Bacteroidetes. The taxonomic status of these bacteria is gradually being explored.

In this study, polyphasic approaches, including phylogenetic analyses based on $16 \mathrm{~S}$ rRNA gene sequences, chemotaxonomic data and phenotypic properties, were used to determine the precise taxonomic position of strain Jip $08^{\mathrm{T}}$, which was isolated in South Korea from rice straw. The results obtained in this study indicated that strain $J i p 08^{\mathrm{T}}$ can be designated a member of the genus Starkeya, but it can be clearly distinguished from $S$. novella. Therefore, we propose $\mathrm{Jip} 08^{\mathrm{T}}$ as the type strain of a novel species, namely Starkeya koreensis sp. nov.

Strain Jip $08^{\mathrm{T}}$ was isolated from rice straw at a farm near Daejeon, South Korea: the rice straw was cut into small pieces and thoroughly suspended in $50 \mathrm{mM}$ phosphate buffer ( $\mathrm{pH} 7 \cdot 0)$. This suspension was spread on R2A agar (Difco) after serial dilution with $50 \mathrm{mM}$ phosphate buffer $\left(\mathrm{pH} \mathrm{7 \cdot 0)}\right.$ and then the plates were incubated at $30^{\circ} \mathrm{C}$ for 3 weeks. Strain $\mathrm{Jip} 08^{\mathrm{T}}$ was one of the dominant morphotypes appearing on the plates in aerobic conditions; it was routinely cultured on $\mathrm{R} 2 \mathrm{~A}$ agar at $30^{\circ} \mathrm{C}$ and maintained as a glycerol suspension $\left(20 \%\right.$, w/v) at $-70{ }^{\circ} \mathrm{C}$. Strain Jip $08^{\mathrm{T}}$ was then deposited in the Korean Collection for Type Cultures as strain KCTC $12212^{\mathrm{T}}$, and at the National Institute of Technology and Evaluation, Japan, as strain NBRC $100963^{\mathrm{T}}$.

The Gram reaction was determined using the non-staining method, as described by Buck (1982). Cell morphology was observed under a Nikon light microscope at $\times 1000$ and in a transmission electron microscope (CM20; Philips) at $\times 27500$. Catalase activity was determined by assessing bubble production in $3 \%(\mathrm{v} / \mathrm{v}) \mathrm{H}_{2} \mathrm{O}_{2}$, and oxidase activity was determined using $1 \%(\mathrm{w} / \mathrm{v})$ tetramethyl-p-phenylenediamine. The utilization of various substrates as sole carbon sources was determined, along with some physiological characteristics, using API 32GN and API 20NE galleries according to the instructions of the manufacturer (bioMerieux). For the degradation of casein, starch and
L-tyrosine (Atlas, 1993; Lewin \& Lounsbery, 1969), reactions were read after 5 days. The hydrolysis of cellulose and xylan was tested as described by Ten et al. (2004). Growth with formate, methanol, methylamine, succinate and oxalate was tested in minimal medium B (Lingens et al., 1985). Tests for growth on sulfur, tetrathionate and thiosufate were done with sulfur medium, tetrathionate broth, thiocyanate utilization medium and thiosufate-oxidizing medium (Atlas, 1993). Negative and positive controls were obtained by inoculating Flavobacterium granuli and $S$. novella, respectively, and observing the turbidity after 10 days. Growth at different temperatures and $\mathrm{pH}$ values was assessed after 5 days incubation. Salt tolerance was measured in R2A broth medium supplemented with $1-10 \%(\mathrm{w} / \mathrm{v}) \mathrm{NaCl}$ after 7 days incubation. To determine the heat resistance of strain $\mathrm{Jip}_{08} 8^{\mathrm{T}}, 0 \cdot 1 \mathrm{ml}$ aliquots of 8 - and 16-h-old cultures that had been treated at three different temperatures $\left(80^{\circ} \mathrm{C}\right.$ for $20 \mathrm{~min}, 90^{\circ} \mathrm{C}$ for $10 \mathrm{~min}$ and $100^{\circ} \mathrm{C}$ for $10 \mathrm{~min}$ ) were inoculated into R2A medium; growth was observed for up to $72 \mathrm{~h}$ at $30^{\circ} \mathrm{C}$. Duplicate antibioticsensitivity tests were done using filter-paper discs containing the following: streptomycin $\left(5,10\right.$ and $15 \mu \mathrm{g} \mathrm{ml}^{-1}$ ) (Mast Diagnostics), tetracycline $\left(5,10\right.$ and $\left.15 \mu \mathrm{g} \mathrm{ml}^{-1}\right)$, kanamycin $\left(1 \cdot 0,1 \cdot 5\right.$ and $\left.2 \cdot 0 \mathrm{mg} \mathrm{ml}^{-1}\right)$ and ampicillin $(30,50$ and $60 \mu \mathrm{g} \mathrm{ml}^{-1}$ ) (Sigma). Discs were placed on R2A plates spread with Jip $08^{\mathrm{T}}$ culture and were then incubated at $30{ }^{\circ} \mathrm{C}$ for 7 days.

The extraction of genomic DNA was performed using a commercial genomic DNA extraction kit (Core Biosystem). The 16S rRNA gene sequence was amplified from the chromosomal DNA by using the universal bacterial primer set (primers 9F and 1512R) and the purified PCR products were sequenced by GenoTech in Daejeon, South Korea (Kim et al., 2005). The full sequence of the 16S rRNA gene was compiled using SeqMan software (DNASTAR). The $16 \mathrm{~S}$ rRNA gene sequences of related taxa were obtained from the GenBank database. Multiple alignments were obtained using the CLUSTAL_X program (Thompson et al., 1997). Gaps were edited in the BioEdit program (Hall, 1999). Evolutionary distances were calculated using the Kimura 
two-parameter model (Kimura, 1983). A phylogenetic tree was constructed using the neighbour-joining method (Saitou \& Nei, 1987) and the maximum-parsimony method (Fitch, 1971) with the MEGA3 program (Kumar et al., 2004) and bootstrap values based on 1000 replications (Felsenstein, 1985).

Isoprenoid quinones were extracted with chloroform/ methanol $(2: 1, \mathrm{v} / \mathrm{v})$, purified via TLC and subsequently analysed by HPLC, as described previously (Collins \& Jones, 1981; Shin et al., 1996). The cellular fatty acids were analysed using cells grown on R2A agar (Difco) for 2 days. The cellular fatty acids were saponified, methylated and extracted according to the protocol of the Sherlock Microbial Identification System (MIDI; Sasser, 1990). The fatty acids were analysed by GC (Hewlett Packard 6890) and identified by using the software package of the Microbial Identification System.

Genomic DNA of strain Jip $08^{\mathrm{T}}$ was extracted and purified with the 100/G genomic-tip system (Qiagen) and then degraded enzymically into nucleosides, as described previously (Mesbah et al., 1989). DNA-DNA hybridization was performed fluorometrically, according to the method developed by Ezaki et al. (1989), using photobiotin-labelled DNA probes and microdilution wells. Five replicate hybridizations were conducted for each sample. The highest and lowest values obtained for each sample were excluded, and the remaining three values were used to calculate similarity values. The DNA relatedness values quoted are the means of these three values.

Strain Jip $08^{\mathrm{T}}$ was found to comprise Gram-negative, highly curved rods $(0 \cdot 4-0 \cdot 8 \times 1 \cdot 2-2 \cdot 0 \mu \mathrm{m})$ (Fig. 2$)$ that occurred singly, in pairs and sometimes in clumps of three to four cells; no filaments were found, even in old cultures. Colonies grown on R2A agar plates for 3 days were smooth, circular, convex and colourless. Spores were never observed and the cells were found to be heat-sensitive. The physiological characteristics of strain Jip $08^{\mathrm{T}}$ are summarized in the species description. The distinguishing characteristics of strain Jip $08^{\mathrm{T}}$ and related type strains are shown in Table 1.

The 16S rRNA gene sequence of strain $\operatorname{Jip} 08^{\mathrm{T}}$ was a continuous stretch of $1406 \mathrm{bp}$. Sequence-similarity calculations obtained after a neighbour-joining analysis indicated that the closest relatives of strain $\mathrm{Jip} 08^{\mathrm{T}}$ were $S$. novella IAM $12100^{\mathrm{T}}(98 \cdot 6 \%)$, Angulomicrobium tetraedale DSM $5895^{\mathrm{T}}$ (98.1\%), Angulomicrobium amanitiforme NCIMB $1785^{\mathrm{T}}$ (98.0\%), Ancylobacter aquaticus ATCC $25396^{\mathrm{T}}$ (96.6\%) and Methylorhabdus multivorans $\mathrm{DM}^{\mathrm{T}}{ }^{\mathrm{T}}$ (95.8\%) (Fig. 1). DNA-DNA hybridization experiments were performed between the type strain of S. novella (IAM $12100^{\mathrm{T}}$ ) and Jip $08^{\mathrm{T}}$ for confirmation of a novel species: the DNA-DNA relatedness value was $15 \%$, which showed that strain Jip $08^{\mathrm{T}}$ belongs to a distinct genomic species (Wayne et al., 1987; Stackebrandt \& Goebel, 1994). Moreover, the two strains could be easily differentiated using tests for the utilization of substrates as sole carbon sources (see Supplementary

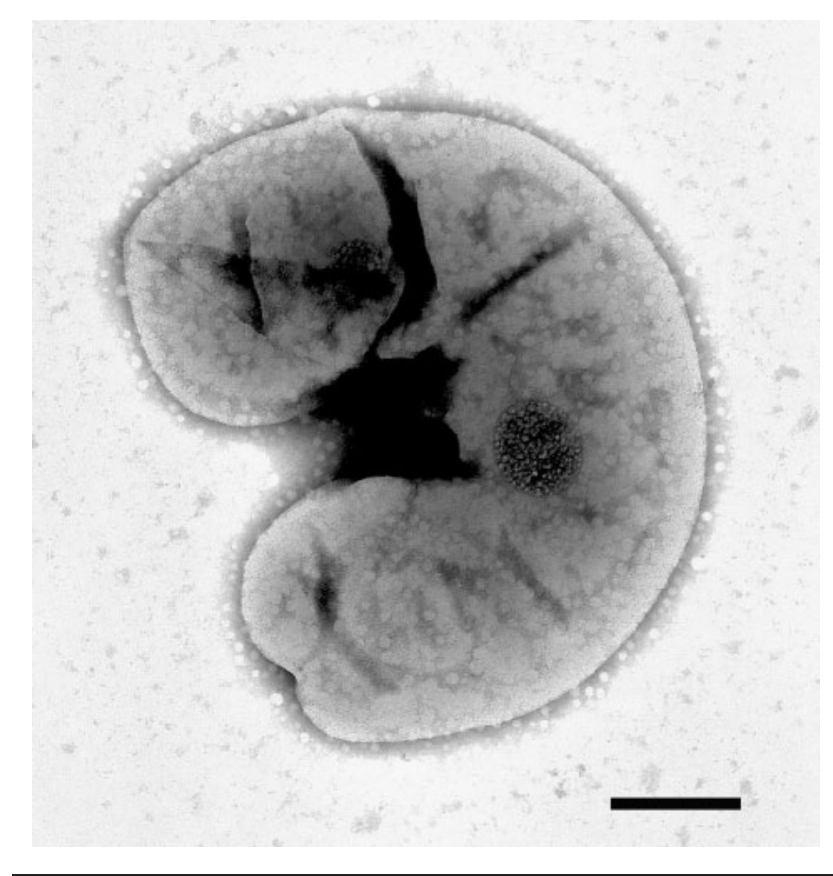

Fig. 2. Transmission electron micrograph of strain $\mathrm{Jip}_{0} 8^{\top}$ from a 3-day-old culture cultivated on R2A agar. Bar, $0.2 \mu \mathrm{m}$.

Table S1 available in IJSEM Online). Although the genera Angulomicrobium, Ancylobacter and Methylorhabdus show high levels of 16S rRNA gene sequence similarity with respect to strain Jip $08^{\mathrm{T}}$, they are clearly distinguishable in the phylogenetic tree (Fig. 1) and on the basis of phenotypic characteristics (Table 1) (Vasil'eva et al., 1979; Raj, 1983; Doronina et al., 1995; Kelly et al., 2000).

Strain $\mathrm{Jip}^{\mathrm{T}} 8^{\mathrm{T}}$ had a genomic DNA G $+\mathrm{C}$ content of $69 \mathrm{~mol} \%$ and a ubiquinone of the Q-10 type. The major fatty acids were $\mathrm{C}_{18: 1}$ isomer (summed feature of $\mathrm{C}_{18: 1} \omega 7 \mathrm{cl}$ $\omega 9 t / \omega 12 t)(66 \cdot 1 \%), \mathrm{C}_{19: 0}$ cyclo $\omega 8 c(23 \cdot 7 \%), \mathrm{C}_{16: 0}(7 \cdot 5 \%)$ and $\mathrm{C}_{18: 0}(2 \cdot 7 \%)$. The major fatty acids of strain Jip $08^{\mathrm{T}}$ were similar to those of the type strain of S. novella (Kelly et al., 2000).

A phylogenetic analysis based on 16S rRNA gene sequence similarity, chemotaxonomic characteristics $[\mathrm{G}+\mathrm{C}$ content of genomic DNA, ubiquinone (Q-10) type, and cellular fatty acid profile] and some ecophysiological and biochemical characteristics (such as the oxidation of thiosulfate and tetrathionate for growth, the optimum temperature and $\mathrm{pH}$ for growth, and the absence of gas vacuoles) clearly shows that strain $\mathrm{Jip}_{08} \mathrm{8}^{\mathrm{T}}$ belongs to the genus Starkeya. However, strain Jip $08^{\mathrm{T}}$ can be distinguished by its low level of DNADNA relatedness $(15 \%)$ with respect to $S$. novella IAM $12100^{\mathrm{T}}$ and its cell morphology (Fig. 2). On the basis of the data and observations described above, strain Jip $08^{\mathrm{T}}$ should be assigned to the genus Starkeya as the type strain of a novel species, for which the name Starkeya koreensis sp. nov. is proposed. 
Table 1. Comparison of distinguishing characteristics of strain $\mathrm{Jip}_{08^{\top}}^{\top}$, S. novella IAM $12100^{\top}$ and related taxa

Strains: 1, strain Jip $08^{\mathrm{T}}$ (data from this study); 2, S. novella IAM $12100^{\mathrm{T}}$ (data from Kelly et al., 2000); 3, Ancylobacter aquaticus ATCC $25396^{\mathrm{T}}$ (data from Raj, 1983, and Xin et al., 2004); 4, Angulomicrobium amanitiforme NCIMB 1785 ${ }^{\mathrm{T}}$ (data from Vasil'eva et al., 1979); 5, Azorhizobium caulinodans ATCC $43989^{\mathrm{T}}$ (data from Dreyfus et al., 1988); 6, M. multivorans DM13 ${ }^{\mathrm{T}}$ (data from Doronina et al., 1995). All species shown are Gram-negative, catalase-positive and positive for growth on glucose. +, Positive; $(+)$, weakly positive or delayed response; -, negative; ND, not determined.

\begin{tabular}{|c|c|c|c|c|c|c|}
\hline Characteristic & 1 & 2 & 3 & 4 & 5 & 6 \\
\hline $\begin{array}{l}\text { DNA G }+ \text { C content } \\
(\mathrm{mol} \%)\end{array}$ & 69 & $67 \cdot 3-68 \cdot 4$ & $66 \cdot 3-67 \cdot 7$ & $67 \cdot 7$ & $66-68$ & $66 \cdot 2$ \\
\hline Cell morphology & $\begin{array}{l}\text { Highly curved } \\
\text { rods }\end{array}$ & $\begin{array}{l}\text { Short rods, coccoidal } \\
\text { or ellipsoidal }\end{array}$ & Curved rods & Mushroom-shaped & Rods & Rods \\
\hline Cell size $(\mu \mathrm{m})$ & $0 \cdot 4-0 \cdot 8 \times 0 \cdot 8-2 \cdot 0$ & $0 \cdot 4-0 \cdot 8 \times 0 \cdot 8-2 \cdot 0$ & $0 \cdot 3-1 \cdot 0 \times 1 \cdot 0-3 \cdot 0$ & $1.0 \times 1 \cdot 5$ & \multicolumn{2}{|c|}{$0.5-0.6 \times 1.5-2.6 \quad 0.4-0.6 \times 1 \cdot 2-2 \cdot 0$} \\
\hline Curved/vibrioid rods, rings & s $\quad+$ & - & + & - & - & Slightly curved rods \\
\hline Arrangement of cells & Single & Single or pairs & Single & Single & Single & Single or pairs \\
\hline Motility & - & - & - & - & + & - \\
\hline Oxidase & + & + & + & + & + & - \\
\hline Temperature range $\left({ }^{\circ} \mathrm{C}\right)$ & $\begin{array}{l}\text { Range, 4-40; } \\
\text { optimum, 28-30 }\end{array}$ & $\begin{array}{l}\text { Range, 10-37; } \\
\text { optimum, 25-30 }\end{array}$ & $\begin{array}{l}\text { Range, 5-43; } \\
\text { optimum, 22-37 }\end{array}$ & $\begin{array}{l}\text { Range, 15-40; } \\
\text { optimum, 28-30 }\end{array}$ & $\begin{array}{c}\text { Range, 12-43; } \\
\text { optimum, ND }\end{array}$ & $\begin{array}{l}\text { Range, 10-45; } \\
\text { optimum, 28-34 }\end{array}$ \\
\hline $\mathrm{pH}$ range for growth & $6 \cdot 5-8 \cdot 0$ & $7 \cdot 0-8 \cdot 0$ & $6 \cdot 8-7 \cdot 0$ & $5 \cdot 2-8 \cdot 0$ & $5 \cdot 5-7 \cdot 8$ & $6 \cdot 8-7 \cdot 4$ \\
\hline Growth with $3 \% \mathrm{NaCl}$ & $(+)$ & - & - & ND & - & - \\
\hline Cyclopropane acid of $\mathrm{C}_{19}$ & + & + & - & + & $\mathrm{ND}$ & + \\
\hline $\begin{array}{l}\text { Cellular hydroxy fatty acid } \\
\text { Growth on: }\end{array}$ & None & None & $\mathrm{C}_{10: 0} 3-\mathrm{OH}$ & None & ND & None \\
\hline Formate & + & + & + & + & - & + \\
\hline Methanol & + & + & + & - & - & + \\
\hline Methylamine & - & - & + & - & - & + \\
\hline Sucrose & - & - & - & - & - & + \\
\hline Maltose & - & - & - & - & - & + \\
\hline Citrate & + & - & + & + & + & $\mathrm{ND}$ \\
\hline Malate & - & - & - & - & + & $\mathrm{ND}$ \\
\hline Succinate & - & - & + & + & + & $\mathrm{ND}$ \\
\hline
\end{tabular}

\section{Description of Starkeya koreensis sp. nov.}

Starkeya koreensis (ko.re.en'sis. N.L. fem. adj. koreensis pertaining to Korea, from where the novel micro-organism was isolated).

Cells are strictly aerobic, Gram-negative, non-spore-forming, non-motile, highly curved rods $0 \cdot 4-0 \cdot 8 \mu \mathrm{m}$ wide and $1 \cdot 2-2 \cdot 0 \mu \mathrm{m}$ long. Cells occur singly, in pairs and sometimes in clumps comprising three or four cells, but do not form filaments. Colonies on R2A and complex medium are circular, convex and colourless and are $0 \cdot 7-1.2 \mathrm{~mm}$ in diameter after 3 days. The temperature range for growth is $4-40{ }^{\circ} \mathrm{C}$; no growth occurs at $42^{\circ} \mathrm{C}$. The optimum temperature for growth is $28-30^{\circ} \mathrm{C}$. The $\mathrm{pH}$ range for growth is between $\mathrm{pH} 6 \cdot 5$ and $8 \cdot 5$, with an optimum between $\mathrm{pH} 7$ and 8 . Growth occurs in the absence of $\mathrm{NaCl}$ and in the presence of $3.0 \%(\mathrm{w} / \mathrm{v}) \mathrm{NaCl}$, but not with $4 \%(\mathrm{w} / \mathrm{v}) \mathrm{NaCl}$. Positive for catalase, oxidase, urease, $\beta$-glucosidase and $\beta$ galactosidase. $\mathrm{H}_{2} \mathrm{~S}$ is not produced. Nitrate is not reduced. Negative for arginine dihydrolase, lysine decarboxylase, ornithine decarboxylase, tryptophan deaminase and gelatinase. Does not produce any acid or gas from glucose. Casein, xylan, chitin, tyrosine, CM-cellulose, DNA and starch are not degraded. The following compounds are utilized as sole carbon sources: glucose, formate, methanol, oxalate, citrate, L-alanine, L-arabinose, propionate, 3-hydroxybutyrate, acetate, DL-lactate and L-proline. The following compounds are not utilized as sole carbon sources: adipate, methylamine, 4hydroxybenzoate, valerate and caprate, mannose, $\mathrm{N}$-acetylglucosamine, maltose, propionate, mannitol, gluconate, malate, phenylacetate, salicin, D-melibiose, L-fucose, Dsorbitol, histidine, 2-ketogluconate, 4-hydroxybutyrate, rhamnose, D-ribose, inositol, D-sucrose, itaconate, malonate, lactate, 5-ketogluconate, glycogen and L-serine. As this species can also utilize thiosulfate or tetrathionate as an energy source, it is facultatively chemolithoautotrophic. Sensitive to $20 \mu \mathrm{g}$ ampicillin $\mathrm{ml}^{-1}, 5 \mu \mathrm{g}$ tetracycline $\mathrm{ml}^{-1}$ and $1.0 \mathrm{mg}$ kanamycin $\mathrm{ml}^{-1}$; resistant to $15 \mu \mathrm{g}$ streptomycin $\mathrm{ml}^{-1}$. The major cellular fatty acids are $\mathrm{C}_{18: 1}$ isomer $(66 \cdot 1 \%), \mathrm{C}_{19: 0}$ cyclo $\omega 8 c(23 \cdot 7 \%), \mathrm{C}_{16: 0}(7 \cdot 5 \%)$ and $\mathrm{C}_{18: 0}(2 \cdot 7 \%)$. The $\mathrm{G}+\mathrm{C}$ content of the genomic DNA of strain Jip $08^{\mathrm{T}}$ is $69 \mathrm{~mol} \%$ (as determined by HPLC).

The type strain, Jip08 ${ }^{\mathrm{T}} \quad\left(=\mathrm{KCTC} \quad 12212^{\mathrm{T}}=\mathrm{NBRC}\right.$ $100963^{\mathrm{T}}=\mathrm{IAM} 15215^{\mathrm{T}}$ ), was isolated from rice straw in Daejeon, South Korea. 


\section{Acknowledgements}

This work was supported by the 2006 Agricultural R \& D Promotion Center Program, Ministry of Agriculture and Forestry, Republic of Korea.

\section{References}

An, D.-S., Im, W.-T., Yang, H.-C. \& Lee, S.-T. (2006). Shinella granuli gen. nov., sp. nov., and proposal of the reclassification of Zoogloea ramigera ATCC 19623 as Shinella zoogloeoides sp. nov. Int J Syst Evol Microbiol 56, 443-448.

Aslam, Z., Im, W. T., Kim, M. K. \& Lee, S.-T. (2005a). Flavobacterium granuli sp. nov., isolated from granules used in a wastewater treatment plant. Int J Syst Evol Microbiol 55, 747-751.

Aslam, Z., Im, W.-T., Ten, L. N. \& Lee, S.-T. (2005b). Phenylobacterium koreense sp. nov., isolated from South Korea. Int J Syst Evol Microbiol 55, 2001-2005.

Atlas, R. M. (1993). Handbook of Microbiological Media. Edited by L. C. Parks. Boca Raton, FL: CRC Press.

Bae, H.-S., Im, W.-T. \& Lee, S.-T. (2005). Lysobacter concretionis sp. nov., isolated from anaerobic granules in an upflow anaerobic sludge blanket reactor. Int J Syst Evol Microbiol 55, 1155-1161.

Beijerinck, M. W. (1904). Phénomènes de réduction produits par les microbes. Arch Neerland Sci Ex Nat 9, 131-157.

Buck, J. D. (1982). Nonstaining ( $\mathrm{KOH})$ method for determination of Gram reactions of marine bacteria. Appl Environ Microbiol 44, 992-993.

Collins, M. D. \& Jones, D. (1981). Distribution of isoprenoid quinone structural types in bacteria and their taxonomic implication. Microbiol Rev 45, 316-354.

Doronina, N. V., Braus-Strohmeyer, S. A., Leisinger, T. \& Trotsenko, Y. A. (1995). Isolation and characterization of a new facultatively methylotrophic bacterium: description of Methylorhabdus multivorans gen. nov., sp. nov. Syst Appl Microbiol 18, 92-98.

Dreyfus, B., Garcia, J. L. \& Gillis, M. (1988). Characterization of Azorhizobium caulinodans gen. nov., sp. nov., a stem-nodulating nitrogen-fixing bacterium isolated from Sesbania rostrata. Int J Syst Bacteriol 38, 89-98.

Ezaki, T., Hashimoto, Y. \& Yabuuchi, E. (1989). Fluorometric deoxyribonucleic acid-deoxyribonucleic acid hybridization in microdilution wells as an alternative to membrane filter hybridization in which radioisotopes are used to determine genetic relatedness among bacterial strains. Int J Syst Bacteriol 39, 224-229.

Felsenstein, J. (1985). Confidence limit on phylogenies: an approach using the bootstrap. Evolution 39, 783-791.

Fitch, W. M. (1971). Toward defining the course of evolution: minimum change for a specific tree topology. Syst Zool 20, 406-416.

Hall, T. A. (1999). BioEdit: a user-friendly biological sequence alignment editor and analysis program for Windows 95/98/NT Nucleic Acids Symp Ser 41, 95-98.

Im, W.-T., Kang, M.-S., Park, H.-Y., Kim, M.-K. \& Lee, S.-T. (2003). Culturable bacterial strain's diversity of environmental samples. In Proceedings of the International Meeting of the Federation of Korean Microbiological Societies, abstract B4023, p. 165. Seoul: Federation of Korean Microbiological Societies.

Kelly, D. P. \& Wood, A. P. (2000). Reclassification of some species of Thiobacillus to the newly designated genera Acidithiobacillus gen. nov., Halothiobacillus gen. nov. and Thermithiobacillus gen. nov. Int J Syst Evol Microbiol 50, 511-516.

Kelly, D. P., McDonald, I. R. \& Wood, A. P. (2000). Proposal for the reclassification of Thiobacillus novellus as Starkeya novella gen. nov., comb. nov., in the $\alpha$-subclass of the Proteobacteria. Int J Syst Evol Microbiol 50, 1797-1802.

Kim, M. K., Im, W.-T., Ohta, H., Lee, M. \& Lee, S.-T. (2005). Sphingopyxis granuli sp. nov., a $\beta$-glucosidase-producing bacterium in the family Sphingomonadaceae in $\alpha-4$ subclass of the Proteobacteria. J Microbiol 43, 152-157.

Kimura, M. (1983). The Neutral Theory of Molecular Evolution. Cambridge: Cambridge University Press.

Kumar, S., Tamura, K. \& Nei, M. (2004). MEGA3: integrated software for molecular evolutionary genetics analysis and sequence alignment. Brief Bioinform 5, 150-163.

La, H.-J., Im, W.-T., Ten, L. N., Kang, M.-S., Shin, D.-Y. \& Lee, S.-T. (2005). Paracoccus koreensis sp. nov., isolated from anaerobic granules in an upflow anaerobic sludge blanket (UASB) reactor. Int J Syst Evol Microbiol 55, 1657-1660.

Lewin, R. A. \& Lounsbery, D. M. (1969). Isolation, cultivation and characterization of flexibacteria. J Gen Microbiol 58, 145-170.

Lingens, F., Blecher, R., Blecher, H., Blobel, F., Eberspächer, J., Fröhner, C., Görisch, H., Görisch, H. \& Layh, G. (1985). Phenylobacterium immobile gen. nov., sp. nov., a Gram-negative bacterium that degrades the herbicide chloridazon. Int J Syst Bacteriol $35,26-39$.

Mesbah, M., Premachandran, U. \& Whitman, W. B. (1989). Precise measurement of the $\mathrm{G}+\mathrm{C}$ content of deoxyribonucleic acid by highperformance liquid chromatography. Int J Syst Bacteriol 39, 159-167.

Quan, Z.-X., Im, W.-T. \& Lee, S.-T. (2006). Azonexus caeni sp. nov., a denitrifying bacterium isolated from sludge of a wastewater treatment plant. Int J Syst Evol Microbiol 56, 1043-1046.

Raj, H. D. (1983). Proposal for Ancylobacter gen. nov. as a substitute for the bacterial genus Microcyclus Ørskov 1928. Int J Syst Bacteriol 33, 397-398.

Saitou, N. \& Nei, M. (1987). The neighbor-joining method: a new method for reconstructing phylogenetic trees. Mol Biol Evol 4, 406-425.

Sasser, M. (1990). Identification of Bacteria by Gas Chromatography of Cellular Fatty Acids. MIDI Technical Note 101. Newark, DE: MIDI.

Shin, Y. K., Lee, J.-S., Chun, C. O., Kim, H.-J. \& Park, Y.-H. (1996). Isoprenoid quinone profiles of the Leclercia adecarboxylata KCTC $1036^{\mathrm{T}}$. J Microbiol Biotechnol 6, 68-69.

Stackebrandt, E. \& Goebel, B. M. (1994). Taxonomic note: a place for DNA-DNA reassociation and $16 \mathrm{~S}$ rRNA sequence analysis in the present species definition in bacteriology. Int J Syst Bacteriol 44, 846-849.

Ten, L. N., Im, W.-T., Kim, M.-K., Kang, M.-S. \& Lee, S.-T. (2004). Development of a plate technique for screening of polysaccharidedegrading microorganisms by using a mixture of insoluble chromogenic substrates. J Microbiol Methods 56, 375-382.

Thompson, J. D., Gibson, T. J., Plewniak, F., Jeanmougin, F. \& Higgins, D. G. (1997). The CLUSTAL_X windows interface: flexible strategies for multiple sequence alignment aided by quality analysis tools. Nucleic Acids Res 25, 4876-4882.

Vasil'eva, L. V., Lafitskaya, T. N. \& Namsaraev, B. B. (1979). New genus of budding bacteria Angulomicrobium tetraedrale having radially symmetrical cells. Mikrobiologiia 48, 1033-1039 (in Russian; English translation pp. 843-849).

Wayne, L. G., Brenner, D. J., Colwell, R. R. \& 9 other authors (1987). International Committee on Systematic Bacteriology. Report of the ad hoc committee on reconciliation of approaches to bacterial systematics. Int J Syst Bacteriol 37, 463-464.

Xin, Y. H., Zhou, Y. G., Zhou, H. L. \& Chen, W. X. (2004). Ancylobacter rudongensis sp. nov., isolated from roots of Spartina anglica. Int J Syst Evol Microbiol 54, 385-388. 
Yang, D.-C., Im, W.-T., Kim, M. K. \& Lee, S.-T. (2005). Pseudoxanthomonas koreensis sp. nov. and Pseudoxanthomonas daejeonensis sp. nov. Int J Syst Evol Microbiol 55, 787-791.

Yang, D.-C., Im, W.-T., Kim, M. K., Ohta, H. \& Lee, S.-T. (2006a).

Sphingomonas soli sp. nov., a $\beta$-glucosidase-producing bacterium in the family Sphingomonadaceae in the $\alpha-4$ subgroup of the Proteobacteria. Int J Syst Evol Microbiol 56, 703-707.

Yang, H.-C., Im, W.-T., Kang, M. S., Shin, D.-Y. \& Lee, S.-T. (2006b). Stenotrophomonas koreensis sp. nov., isolated from compost in South Korea. Int J Syst Evol Microbiol 56, 81-84. 